\title{
NÉPESSÉG, SZELEKCIÓ, OKTATÁS
}

\author{
FEHÉRVÁRI ANIKÓa,* - HÍVES TAMÁS - SZEMERSZKI MARIANNA \\ ${ }^{a}$ ELTE PPK Neveléstudományi Intézet
}

Beérkezett: 2021. március 22., elfogadva: 2021. június 4.

Írásunk a középiskolai és a felsőoktatási felvételi adatokat felhasználva mutatja be az elmúlt évtizedek beiskolázási trendjeit, fókuszálva az elmúlt másfél-két évtizedben végbemenő folyamatokra. A középiskolai beiskolázás adatai szerint egyrészt megállapítható, hogy a rendszerváltás utáni trend 2011 után megtört, a középiskolás korosztályon belül egyre csökken azok aránya, akik részt vesznek valamilyen középfokú képzésben, másrészt a képzésben maradók preferenciái ugyan az általános képzés felé törekednek, de a felvettek számát és arányát tekintve mégis a szakképzésben tanulnak többen. A felsőoktatásba újonnan bekerülők jelentős hányadát adják a frissen érettségizettek, akiknek a létszáma az utóbbi 15 évben folyamatosan csökken, ezzel egyidejüleg azonban a részidős képzésekben tanulók létszáma is meredeken visszaesett.

Kulcsszavakः beiskolázás, szelekció, közoktatás és felsőoktatás

The study presents enrolment trends using secondary and tertiary enrolment data, focusing on trends over the last two decades. The data on secondary school enrolment shows that, on the one hand, the post-transition trend was broken after 2011, with the proportion of secondary school students enrolled in some form of upper secondary education decreasing, and on the other hand, while the preferences of those who remain in education are tending towards general education, more people are enrolled in vocational education and training in terms of both the number and the proportion of enrolments. A significant proportion of new entrants to higher education are recent graduates from secondary education, whose number have been declining steadily over the last 15 years, but at the same time the number of part-time students in higher education has also fallen sharply.

Keywords: enrolment, selection, public and higher education

* Levelező szerző: Fehérvári Anikó, ELTE PPK Neveléstudományi Intézet, 1075 Budapest, Kazinczy utca 23-27. E-mail: fehervari.aniko@ppk.elte.hu 


\section{Bevezetés}

A tanulmány azt vizsgálja, hogy hogyan változtak a tanulói, hallgatói preferenciák, a bekerülési esélyek a középfokú és felsőfokú képzésben, és ennek hátterében milyen okok húzódhatnak meg. Az elemzés alapját a KIFIR és a Felvi adatbázisok adják, amelyek a középiskolai és felsőoktatási felvételi eljárás reguláris adatgyűjtései. A KIFIR informatikai rendszer 2000 óta müködik Magyarországon, feladata a középiskolai felvételik bonyolítása, a jelentkezések regisztrálása. 2016-ban a középfokú iskolák megnevezésében jelentős változás történt, csak a gimnáziumok maradtak a régi nevükön. A szakközépiskolákból szakgimnáziumok, majd technikumok, a szakiskolákból szakközépiskolák, a speciális szakiskolákból szakiskolák lettek. Elemzésünk hosszú távú idősorokat dolgoz fel, ezért az egyszerűség és az összehasonlíthatóság kedvéért maradtunk a régi elnevezéseknél (Fehérvári-Hives 2017a,b).

A magyar felsőoktatási intézményekbe központi eljárás keretében lehet jelentkezni alap-, mester- és osztatlan képzésekre, továbbá felsőoktatási szakképzésre évente kétszer, általános és keresztféléves eljárásban. Ezeket a jelentkezési és felvételi adatokat adatbázisokban összesítik, s a felvi.hu felületen az érdeklődők számára nyilvánosságra hozzák. Jelen tanulmányban csak az általános eljárások adataira építünk, ezen belül is elsősorban az érettségire épülő képzések adatait vizsgáljuk. A felsőoktatásban zajló folyamatok és a demográfiai összefüggések pontosabb feltárásához ugyanakkor a Felvi adatokon kívül a hallgatói populáció összetételét bemutató idősoros adatokat is figyelembe veszünk.

\section{Közoktatás és népesedés}

A középfokú beiskolázás adatainak vizsgálata előtt két adatsor bemutatása nélkülözhetetlen ahhoz, hogy megértsük az iskolai továbbhaladás ezredforduló utáni folyamatait. Az 1. ábra az 1990 és 2018 közötti demográfiai trendeket mutatja be. A magyar közoktatásnak egy tartósan leszálló demográfiai trendre kell felkészülnie, amelyben az újonnan született korosztályok egyre csökkenő létszámúak. Látható, hogy a születések száma alapján mintegy másfél évtizedig a középfokra lépő korosztály korábban erősen csökkenő nagysága kisebb eltérésekkel ugyan, de szinten maradt. A legnagyobb esés a kilencvenes években következett be, míg 1990-ben 125 ezer felett volt a születésszám, 1997-re százezer alá csökkent. 2018-ban pedig 90 ezer alá került az újszülöttek száma. Így a középfokú beiskolázást alapvetően érintő 14 éves korosztály számának nagysága folyamatosan csökkent 1990 óta. Ugyanakkor a beiskolázási adatok azt mutatják, hogy ez a demográfiai apály csak 2007 után jelentkezett a középfokú képzésben, mivel a képzés lefelé ( 6 és 8 osztályos gimnáziumi képzés, 0 . évfolyamok bevezetése) és felfelé terjeszkedése (érettségi utáni szakképzés) az egyre csökkenő korosztályokat egyre hoszszabb ideig tartotta benn az oktatásban.

A 2. ábra is ezt támasztja alá. Az adatok a középfokú képzésben részt vevők számát, valamint hozzájuk viszonyítva a 15-18 éves korosztály arányát mutatja. Megállapítható, hogy a rendszerváltást követően meredeken emelkedik a középfokú képzésben részt vevők aránya, ugyanakkor az is látható, hogy 2011 után ez folyamat megtorpan és csökken a 15-18 éves korosztály képzésben való részvétele. 2011 és 2019 között 10,7\%kal csökkent a képzésben lévők aránya, 2019-ben a korosztály 85,6\%-a volt az oktatás- 
NÉPESEDÉS ÉS OKTATÁS

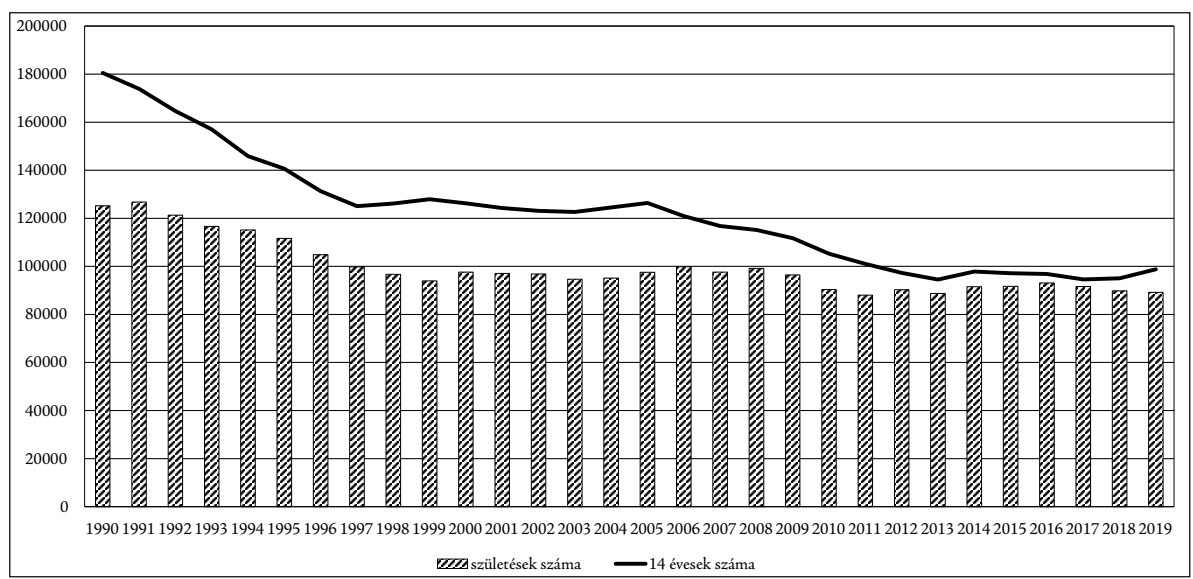

1. ábra: 14 éves korosztály nagysága 1990-2019 között. Forrás: KSH

ban. Ez köszönhető a tankötelezettségi korhatár lejjebb szállításának (2011-ben 18 éves korról 16 éves korra módosult), valamint a középfokú iskolarendszer szerkezeti átalakításának is, aminek következtében rövidült a képzési idő, amely föként a szakképzést érintette. 2013 óta a szakiskolai képzés a korábbi 2+2 vagy 3 éves képzésről 3 évre módosult, 2016-tól pedig a szakközépiskolai/szakgimnáziumi, a mai technikumi képzés is átalakult. A technikum a képzés idejére vonatkozóan nem hozott változást (4+1 év), viszont tartalmát tekintve mindinkább előtérbe került a szakmai képzés az általános képzés kárára. Ami köszönhető annak, hogy az iskolarendszerü szakképzés tartalmát mindig is két terület (közoktatás és foglalkoztatás) egyeztetése határozta meg. Ebben az együttműködésben a foglalkoztatási terület meghatározóvá, egyeduralkodóvá vált, így a szakképzés és annak tartalma is szinte kizárólag a gazdasági szereplők érdekei alá rendelődik. Különösen a Magyar Kereskedelmi és Iparkamara törekvései jelennek meg a szakképzéspolitikában (Mártonfi 2019).

Nemzetközi összehasonlításban, az OECD EAG 2018-as adata alapján, Magyarországon a 15-19 éves korosztály 83\%-a volt az iskolarendszerben, ez elmarad az OECD

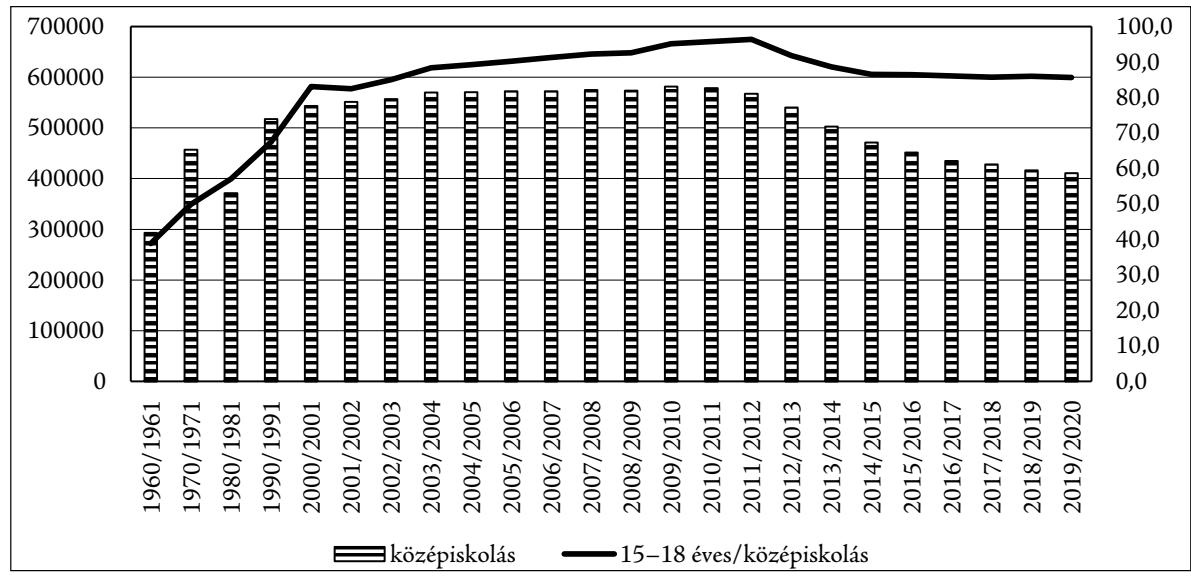

2. ábra: A középiskolások száma (fö) és a 15-18 éves korosztály aránya (\%), 1960-2019 között. Forrás: KSH 
átlagától (84\%) és az EU-átlagtól is (88\%), valamint a visegrádi országokétól is, ahol Cseh- és Lengyelország 90-93\%-os korosztályaránya mellett némileg Szlovákiáé is több (84\%), mint a magyar arány (OECD 2020).

\section{Szelekció középfokon}

A magyar iskolarendszer 1990 után is megtartotta a 8 osztályos általános iskolai képzést. Ugyanakkor 1985 után az oktatáspolitika utat nyitott a 6 és 8 osztályos gimnáziumi képzésnek is, így az egységes alapiskolai képzés már 4 évfolyam után megbomlik. $\mathrm{A} z$ általános iskolát követően háromféle képzés közül választhatnak a tanulók: gimnáziumi, szakközépiskolai (szakgimnázium, technikum) és szakiskolai (szakközépiskolai, szakképző iskolai). Míg a gimnáziumi és a szakközépiskolai képzés érettségivel zárul, amely a felsőoktatás bemeneti feltétele, addig a szakiskolai képzés alapvetően a munkaerőpiaci kimenettel zárul.

A középiskolai jelentkezés során a tanuló bármennyi iskola bármennyi tagozatát ${ }^{1}$ megjelölheti, a tanuló/szülő elsődleges preferenciáját az első helyen megjelölt iskola és tagozat jelzi. A 3. ábra szemléletesen mutatja be, hogy miként alakultak az első helyen történő jelentkezések, illetve milyen különbségek mutatkoznak a képzési típusok között. $\mathrm{A} z$ idősoros ábrából egyértelműen látszik, hogyan változott a különböző képzésekbe jelentkezők aránya. Az elmúlt húsz évben folyamatosan emelkedett a gimnáziumba jelentkezők aránya, 2001-ban még csak a jelentkezők 30\%-a írt be első helyen valamilyen gimnáziumot, 2019-ban már 48,5\%-uk.

Ez az erőteljes növekedés jelzi, hogy a tanulók, illetve a szüleik elsősorban a gimnáziumi képzést látják sikeresnek és fontosabbnak iskolai továbbhaladásuk szempontjából. Ennek hátterében az áll, hogy a gimnáziumokból lehet nagyobb eséllyel továbbtanulni a felsőoktatásban. Ugyan a gimnázium mellett a szakközépiskolában végzetteknek is van lehetőségük a felsőfokú továbbtanulásra (hiszen mindkét iskolatípus érettségivel zárul), mégis a gimnáziumokból érkezők a szakközépiskolásokhoz képest jobb eséllyel tervezhetnek felsőfokú továbbtanulást, a két képzés közötti esélykülönbségek a kétezres évekhez képest egyre inkább nőnek, s a szakközépiskolások körében fokozódik az önszelekció is, vagyis egyre kisebb arányban jelentkeznek felsőfokra (Szemerszki 2014). Emellett a szakképzés 2016-os átalakulása nyomán ebből a képzésből már csak szakirányú felsőoktatás felé vezet egyenes út, vagyis jelentősen korlátozottá válnak a továbbtanulási lehetőségek, irányok. Ezek a korlátok a halasztott döntéseket és pályakorrekciókat is megnehezítik. Megjegyezzük azonban, hogy a gimnáziumi jelentkezések csúcsa 2017-ben és 2018-ban volt (49,5\%), 2019-re egy százalékot esett az ide jelentkezők száma.

A gimnáziumi jelentkezők trendszerü növekedése a szakképzésbe jelentkezések változásával járt együtt, hiszen ahogy a gimnáziumi jelentkezések száma nőtt, úgy esett a szakközépiskolába jelentkezőké. Az idősoros adatok azt mutatják, hogy 2007 jelentett fordulópontot, amikor jelentős törés következett be a két intézménytípusba való jelentkezésben, megugrott a gimnáziumokba és jelentősen csökkent a szakközépiskolákba

1 A három fő képzésen belül számtalan tagozat létezik: a szakképzésben alapvetően szakmacsoportok szerinti tagozatok, míg az általános képzésben nyelvi tagozatok, két tanítási nyelvű tagozatok és egyéb tantárgyakat kiemelt óraszámban tanító tagozatok vannak. A tagozatok eltérő képzési időt is megjelölhetnek, így a tipikusnak számító 4 éves középiskolai képzés 5 éves is lehet. 


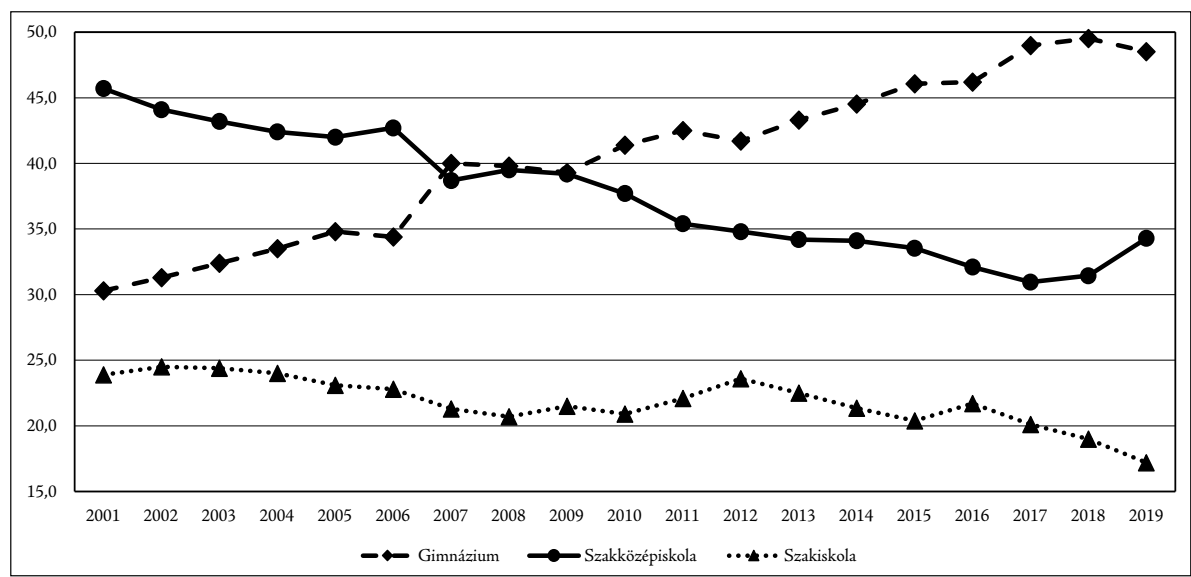

3. ábra: Hova jelentkezett első helyre, képzési típus szerint (\%). Forrás: KIFIR

jelentkezők száma. Ez volt az első év, amikor a gimnáziumban továbbtanulni szándékozók aránya meghaladta a szakközépiskolákba jelentkezőkét. A 2000-es évek elején még 15,4 százalékpontnyi előnyben volt a szakközépiskola a gimnáziumhoz képest, amely az évek során lassan leapadt, és 2019-re a gimnáziumoknak van 14 százalékpontos előnyük. (Megjegyezzük, hogy 2018-ban volt a legnagyobb az előny, 18\%.)

A szakiskolákba továbbtanulók aránya lassabban változott, némi hullámzással azonban csökkenő tendenciát mutat. A 2010-es évek elején ugyan ismét növekedni kezdett az ide jelentkezők aránya, azonban ez a folyamat 2012-ben megtorpant, és azóta is csökkenő tendenciát mutat, 2019-ben mindössze 17,2\% volt a jelentkezők aránya ebbe a képzésbe. Vagyis egyértelmüen kimondható, hogy az oktatáspolitika folyamatos erőfeszítései ellenére sem tudta a képzés pozícióját megváltoztatni.

A jelentkezés, különösen az első helyen történő jelentkezés, még nem jelenti azt, hogy valóban abban a képzési típusban is kezdi meg tanulmányait a tanuló, inkább csak a tanulói, szülői igényeket, vágyakat mutatja. A 4. ábra az elmúlt közel két évtized felvételi arányait ábrázolja intézménytípusok szerint. Jól látható, hogy a gimnáziumi kép-

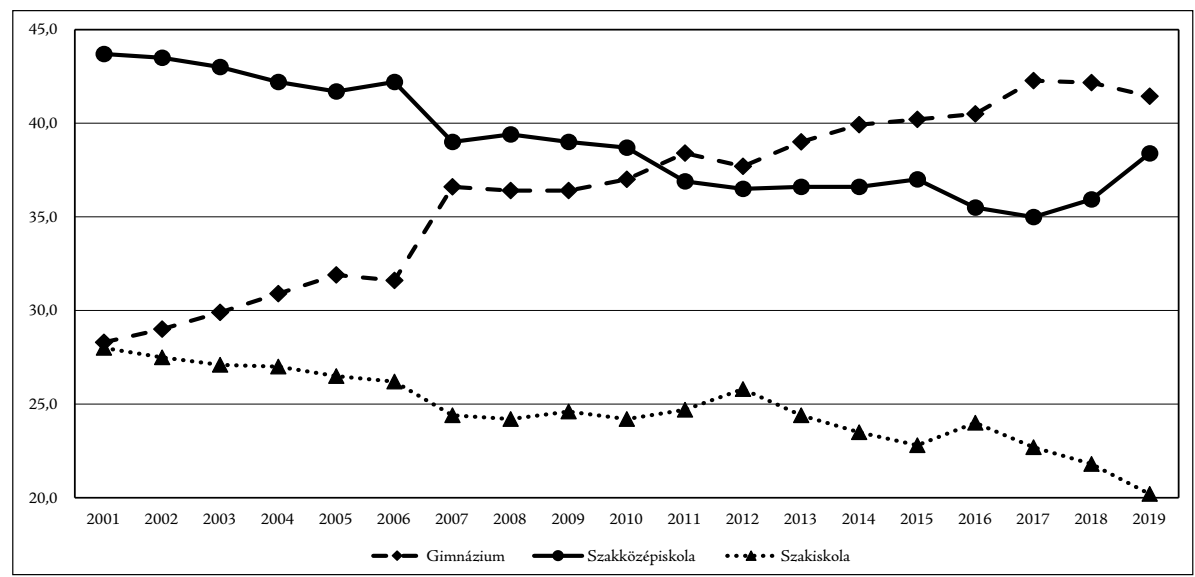

4. ábra: Hova vették fel, képzési típus szerint (\%) - 2001-2019. Forrás: KIFIR 
zés felülkerekedése közel sem mutatható ki olyan arányban, mint a jelentkezéseknél. A felvettek esetében csak 2011-től haladja meg a szakközépiskolás felvettek arányát a gimnazistáké. 2011-ben a gimnáziumokba az oda jelentkezők 38,4\%-át vették fel, a szakközépiskolákba pedig a 36,9\%-át. 2017-ig folyamatosan nőtt a különbség a két képzésbe felvettek között (7,3\%), majd az elmúlt három évben ismét közelít egymáshoz a két adatsor.

A jelentkezéseket és a felvettek számát összehasonlítva, a gimnáziumi képzésbe volt a legnehezebb a bekerülés. Ráadásul, ha a jelentkezők és a felvettek arányának különbségét megvizsgáljuk, akkor azt tapasztaljuk, hogy ez egyre nagyobbá vált az évek során (5. ábra). Míg 2000-ben csak a jelentkezők 6\%-a nem került be gimnáziumi képzésbe, addig 2019-re ez az arány 22\% volt. Vagyis a gimnáziumok a demográfiai apály mellett is vonzóbbak tudtak maradni és jobban tudnak válogatni a tanulók között, mint a többi iskolatípus. A szakképzésben a szakiskolákba régebben is bárki bekerülhetett, a szakközépiskolákban azonban 2001-ben még nagyobb volt a szelekció, mint a gimnáziumokban. Ez azonban az évtized végére, 2010-re megváltozott, akkor már minden oda jelentkezőt felvettek. Ez ma is így van, bár úgy tűnik, hogy a legnagyobb képzéstől való elforduláson (2015, illetve 2016) túlvan a szakközépiskola. Valószínű, hogy a 2016os átalakulás és az azt megelőző kommunikáció elbizonytalanította az ide jelentkezőket, és inkább a gimnáziumokba terelte a tanulókat. Viszont az elmúlt egy-két évben megerősödni látszik a szakközépiskolai/technikumi képzés. Az, hogy ez a tendencia mennyire stabil, még nem dönthető el az adatok alapján.

A szakiskolai képzésbe az első helyen jelentkezők aránya nem érte el a végül ide bekerülőkét, a bekerülők aránya már 2001-ben is meghaladta az ide jelentkezők arányát és ez nem változott az elmúlt két évtizedben.

A létszámadatok azt mutatják, hogy 9. évfolyamon még soha ennyien nem folytatták gimnáziumokban a tanulmányaikat, mint az utolsó vizsgált évben (6. ábra). 2013-tól folyamatosan emelkedik ez a szám, 2019-ben 41758 gimnazista tanult 9. évfolyamon. 2013 volt az első év, amikor többen kezdték meg gimnáziumi tanulmányaikat, mint a szakközépiskolait (technikumit). A szakképzésben lezajlott változások visszavetették a beiskolázási létszámot. Habár a szakközépiskola (technikum) láthatóan a 2016/2017-es

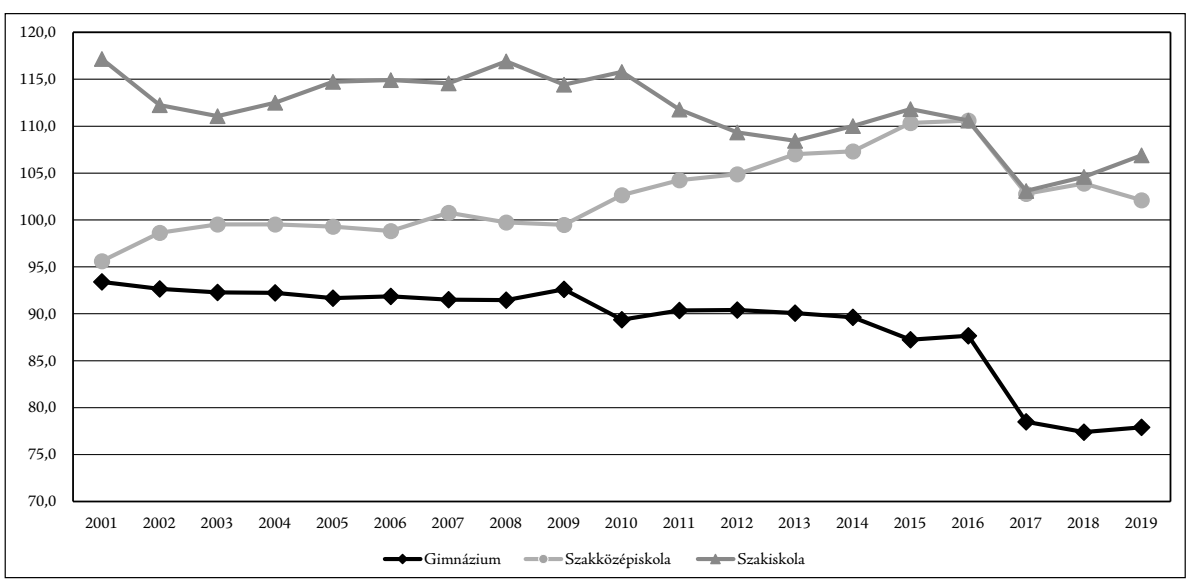

5. ábra: Az első helyen jelentkezők és felvettek aránya képzési típusonként, 2001-2019. Forrás: KIFIR 


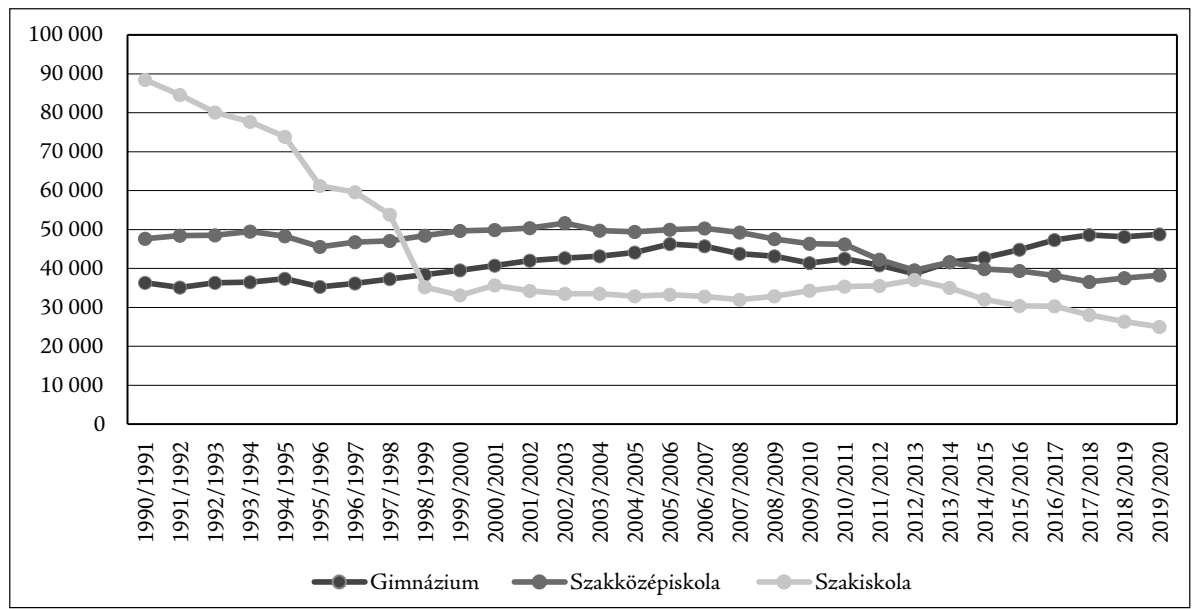

6. ábra: A kilencedik évfolyamon tanulók száma 1990-2019 között. Forrás: KIR-STAT

hullámvölgyből igyekszik megerősödni, mégis mára már tízezer tanulóra nőtt a különbség a beiskolázásban a két, érettségit adó képzés között.

A klasszikus szakmunkásképzés (szakiskola vagy mai nevén szakközépiskola) viszont egyre kevesebbek számára vonzó. A kilencvenes évek hihetetlen nagy létszámú évfolyamai a kétezres évekre 33-35 ezer újonnan belépő tanulóra estek vissza, 2013 óta pedig további folyamatos csökkenés figyelhető meg, melynek révén 2019-ben már csak 25 ezer tanuló kezdte meg itt a képzést. Mindez nemcsak annak szól, hogy a képzés már nem tud vonzó lenni a fiatalok számára, hanem a háttérben az is meghúzódik, hogy a korosztály 15\%-a már nincs az iskolarendszerben középiskolás korára.

\section{Állami és magánoktatás}

A szakképzés mindkét képzési programjába nagyobbak a bekerülési esélyek, míg az általános képzésben folyamatosan szükülnek. A következőkben azt vizsgáljuk meg, hogy szektoronként hogyan változtak a képzéstípusok és a különböző szektorokban képzésenként hogyan változtak a bekerülés esélyei. Ehhez három év - 2013, 2016 és 2019 - adatait használtuk fel, melyet az is indokol, hogy 2013 és 2016 hozott változást a szakképzésben, és a 2019-es adatok a legfrissebben elérhetők.

A szakképzési szektorban (7. ábra) hat év alatt az állami szerepvállalás felerősödött, a szakközépiskola/technikum esetében öt, míg a szakiskolák/szakközépiskolák körében három százalékkal növekedett az állami fenntartásban müködő intézmények száma. Mindez úgy változott, hogy közben az egyházi fenntartású intézmények aránya alig változott, továbbra is $11-12 \%$ közötti. Vagyis az állami szerepvállalás a magán- és az alapítványi működésben lévő intézmények visszaszorulásával járt együtt.

$\mathrm{A} z$ általános képzésben az állami férőhelyek terén a legnagyobb mértékü csökkenés a négy-, illetve ötosztályos gimnáziumi helyek számában következett be (8. ábra). A vizsgált hat évben 69\%-ról 59\%-ra esett az állami fenntartásban müködő intézmények férőhelyeinek száma. Az átrendeződésben az egyházi és a magánszektor is növekedett, míg az előbbi 5, addig az utóbbi 3\%-kal. Ugyanakkor emelkedett a magánfenntartású gimnáziumokba járók aránya is, elsősorban a négy-, illetve ötosztályos gimnáziumokban. Az 
FEHÉRVÁRI A. - HÍVES T. - SZEMERSZKI M.: NÉPESSÉG, SZELEKCIÓ, OKTATÁS

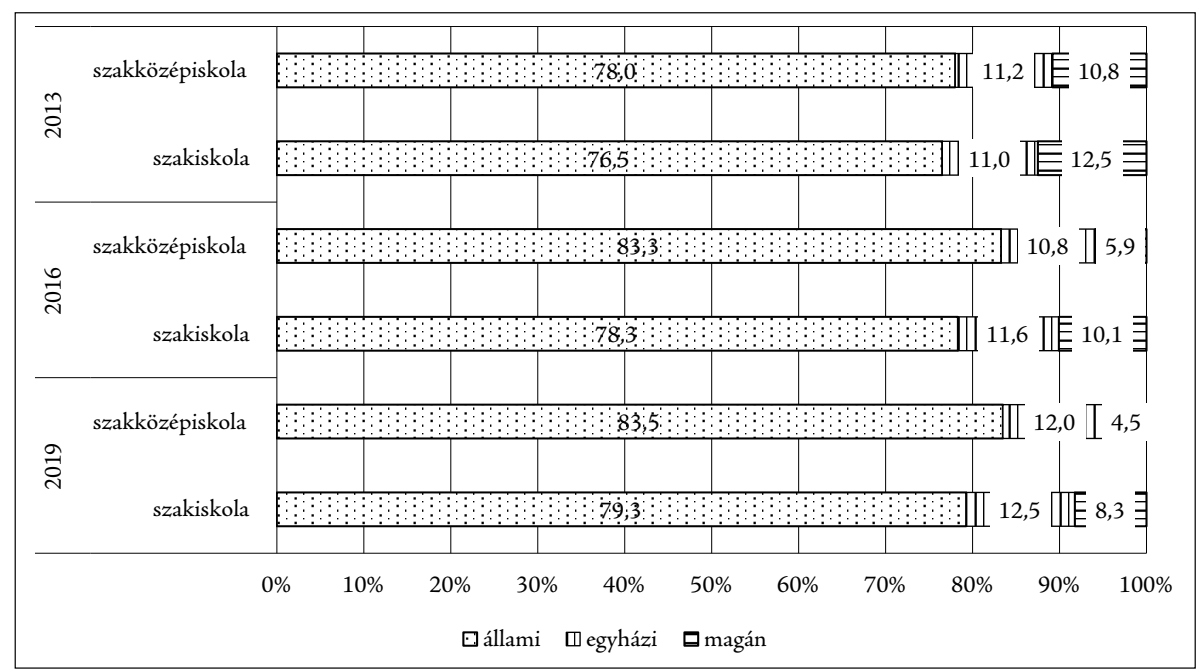

7. ábra: A meghirdetett férőhelyek a szakképzés típusa és az iskola fenntartója szerint, 2013-2019. Forrás: KIFIR

egyházi oktatás előretörésével, a fenntartói átrendeződés folyamataival több tanulmány is foglalkozott korábban (Hermann-Varga 2016; Tomasz 2017).

A bekerülési esélyekről megállapítható, hogy az általános képzésben az állami intézményekbe nehezebb a bekerülés, mint az egyházi és a magániskolákba, valamint a négy- és ötosztályos képzésbe mindenhol könnyebb bekerülni, mint a hat- és nyolcosztályosba.

A gimnáziumi adatokat részleteiben vizsgálva látható, hogy az állami nyolcosztályos képzésbe a jelentkezők alig több mint fele kerül be (9. ábra). Ennél valamivel jobb a hatosztályos képzésbe kerülők aránya. Az egyházi fenntartású intézményekben is csökkent a vizsgált hat év alatt a bekerülés esélye, míg 2013-ban a jelentkezők 80\%-át felvették, addig 2019-ben csak a kétharmadát. A magán- és az alapítványi fenntartású iskolákban

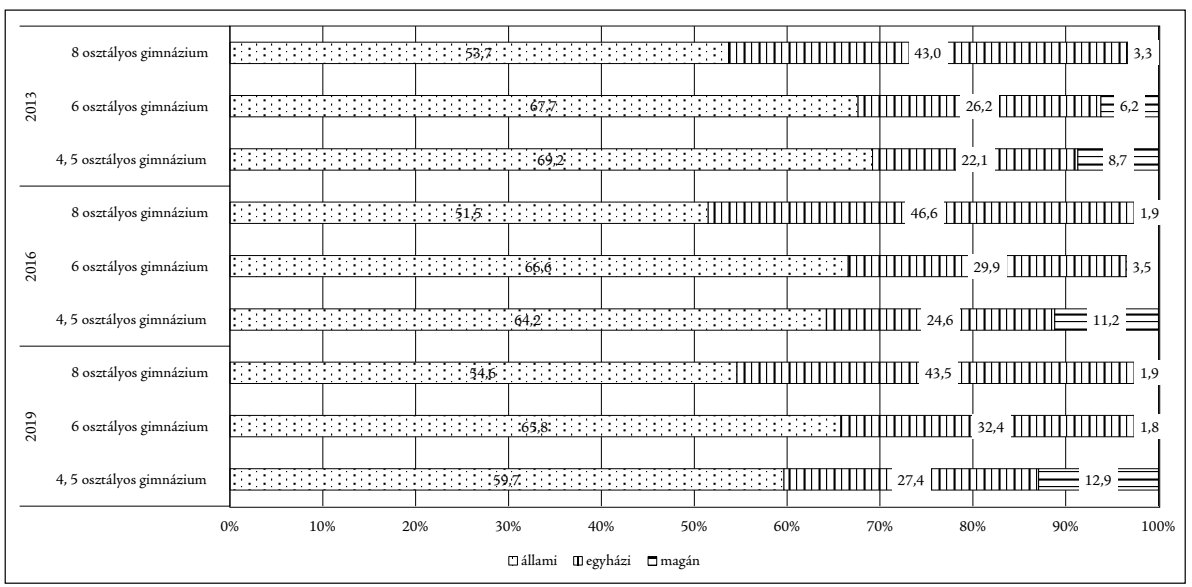

8. ábra: A meghirdetett férőhelyek az általános képzés típusa és az iskola fenntartója szerint, 2013-2019. Forrás: KIFIR 


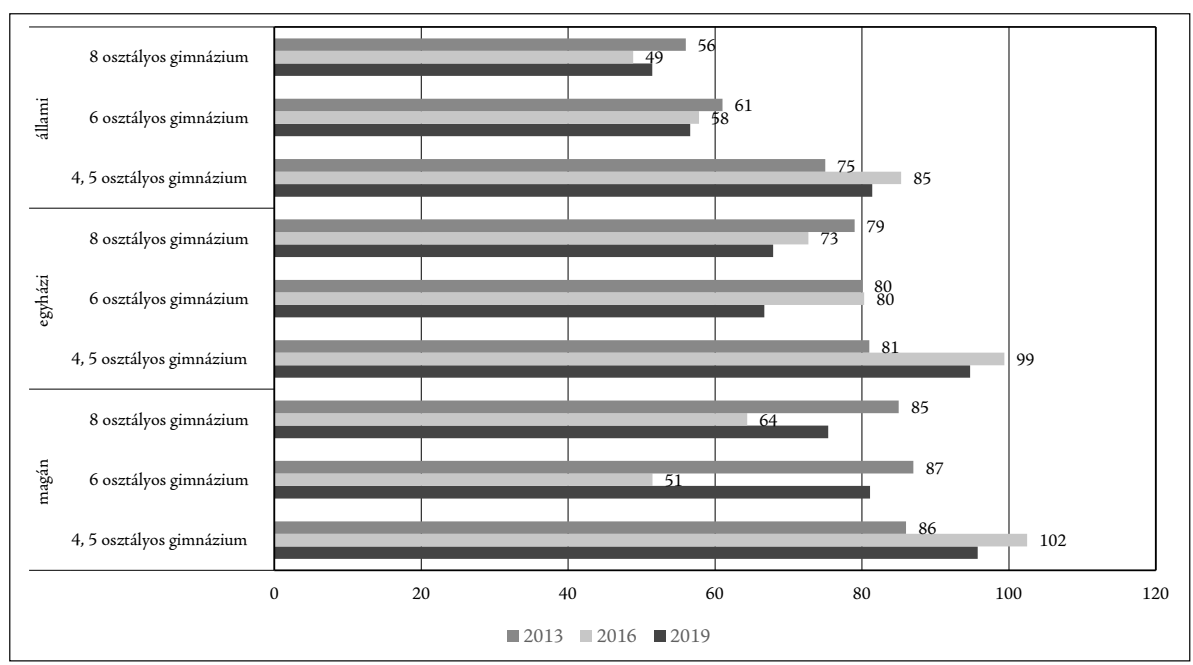

9. ábra: Bekerülési esélyek változása a gimnáziumi képzésekbe iskolafenntartók szerint, 2013-2019. Forrás: KIFIR

nem rajzolódik ki egyértelmű trend. A három intézményfenntartó összehasonlításában itt a legnagyobb a bekerülési esély a szerkezetváltó gimnáziumok esetében (itt viszont biztosan tandíjra számíthat a jelentkező).

A négy- és ötosztályos gimnáziumok már kevésbé szelektálnak, de ott is jellemző, hogy az állami intézményekbe kisebb a bekerülés esélye, mint az egyházi és a magániskolákba. E két utóbbi szektor intézményeiben hasonlóan alakultak az esélyek 2019. ben. A vizsgált három év adatai nem egyirányúak, de elmondható, hogy 2013-hoz képest 2019-ben könnyebb bekerülni a 4 és 5 osztályos gimnáziumokba bármelyik szektorban.

Az előzőekben tanulói szempontból vizsgáltuk a bekerülési esélyeket. Emellett azt is megnéztük, hogy az intézmények mennyire tudják azokat a tanulókat felvenni, akiket szeretnének. A jelentkezések és az elért pontszámok alapján a felvételi rendszer rangsort készít, de mivel a diák több helyre is jelentkezhet, így ha az első helyre felveszik, akkor az általa megjelölt további helyeken a rangsorban a következő léphet a helyére. (Például, ha valaki a Trefortba szeretne bekerülni első helyen, de megjelölte az Eötvöst is, és mindkét helyen az adott iskola rangsorában az első helyen szerepel, akkor az Eötvösben már automatikusan a második helyre rangsorolt lesz az első helyen felvett diák.) Tehát a meghirdetett helyek és a felvettek között a legalacsonyabb rangsorszám aránya azt mutatja meg, hogy az adott intézmények mennyire tudták felvenni az általuk előre rangsorolt tanulókat. A 2019-es felvételi adatok alapján elmondható, hogy a magánés az alapítványi iskolákra jellemző, hogy azokat veszik fel, akiket előre rangsoroltak. A magán hat- és nyolcosztályos gimnáziumok esetében ez az arányszám 1,01 és 1,04, a négyosztályos gimnáziumok esetében valamivel magasabb ez az érték, 1,28. Az egyházi fenntartásban lévő intézmények esetében némileg magasabbak ezek arányszámok $(1,19,1,28$ és 2,03), míg az állami iskolákban a legmagasabbak $(1,83,1,37$ és 3,08). Mindez azt jelzi, hogy a magán- és alapítványi, valamint az egyházi iskolákba jelentkezéseknél is tetten érhető egy (anyagi, világnézeti alapú) önszelekciós mechanizmus, 
így a bekerülési esélyek azért is kedvezőbbek a nem állami szférában, mert ott már a jelentkezés előtt végbemegy egy előzetes szelekció. ${ }^{2}$

\section{Felsőoktatás és demográfia}

A felsőfokon tanulók létszáma a 2000-es évek elején érte el a csúcspontját, akkor valamivel több mint 400 ezer hallgató tanult a felsőoktatás különböző szintjein. A hallgatók jelentős része részidős képzésben vett részt, amelynek részaránya az 1990-es évek eleji 27\%-os mértékről 2002-2005 között 47\%-osra nőtt. Bár a nappali képzésben részt vevők részaránya csökkent ebben az időszakban, itt is erőteljes létszámbeli felfutás volt tapasztalható, hiszen az 1990-es évek eleji 100 ezer fö körüli nappali hallgatói létszám a kétezres évek elejére megduplázódott. A létszámok növekedése egyrészt a korábban is meglévő, ámde ki nem elégített lakossági igényekkel volt összefüggésben, másrészt a fiatalabbak körében növekvő továbbtanulási hajlandóság is generálta, ráadásul a frissen érettségizettek száma is ebben az időszakban érte el a legmagasabb értéket (Hives-Kozma 2014).

A felsőoktatási expanzió csúcspontjához képest az utóbbi 15 évben fokozatos létszámcsökkenés figyelhető meg, amely kétségtelenül részben demográfiai okokkal magyarázható, de nem kizárólag azzal. Amint azt a 10. ábra adatai is mutatják, a hallgatói létszámcsökkenés elsődlegesen a nem nappali képzésekben tanulók létszámának erőteljes csökkenésével van összefüggésben, márpedig tudható, hogy a nem nappali munkaformát elsősorban nem a frissen érettségizettek választják (Garai-Kiss 2014; Veroszta 2010). Az idősoros adatokat tekintve a nem nappali képzéseken belül is átstrukturálódás figyelhető meg, nevezetesen a mindig is számottevő levelező munkarend egyre dominánsabbá válása. Olyannyira, hogy míg az összes képzési formát tekintve 2000 körül még több mint 10 ezer hallgató tanult esti képzésben és több mint 30 ezer távoktatási formában, addig mára az esti képzésben tanulók száma alig 3 ezer före csökkent, s a távoktatás

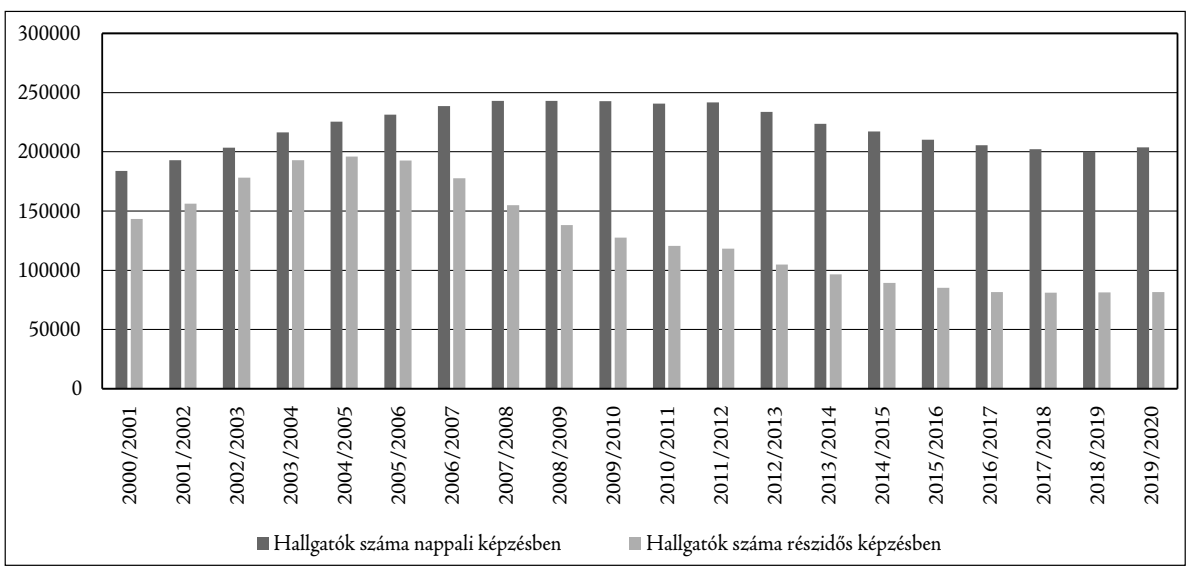

10. ábra: A hallgatói létszám alakulása (2000-2020). Forrás: KSH STADAT

2 Köszönet Lannert Juditnak, aki e gondolathoz az ötletet adta, és használta ezt a számítást Sugár Andrással együtt a 2000. és 2001. évi középiskolai felvételi rendszer adatbázisának elemzését tartalmazó tanulmányában (kézirat). 
munkarend is 5 ezer fó alatti létszámot jelent. Mindez azt eredményezi, hogy a 2000-es évek eleji $70 \%$-os arányhoz képest a részidős képzésekben tanulók kilenctizede ma már levelező képzésben vesz részt.

Bár összességében a hallgatói létszám egyenletes csökkenése jellemző, s ezen belül az utóbbi néhány évben a létszámok mind a nappali, mind a részidős képzésben stabilizálódni látszanak, mindez csak részben mondható el a jelentkezési és felvételi létszámokra, amelyek sokkal hektikusabban változnak. Ebben a tekintetben ugyanis az időről időre bekövetkező képzésszerkezeti és jogszabályváltozások is jelentős befolyással bírnak arra, hogy egy adott évben mennyien kívánnak bekerülni a felsőoktatásba, milyen képzésekre és milyen eséllyel jutnak be. A nappali képzésre jelentkezők (és felvettek) létszáma összességében valamivel stabilabbnak mutatkozik, mint a részidős képzésekre jelentkezőké (és felvetteké), ami több okra vezethető vissza. Levelező képzésben a 2004-es csúcspontot követően erőteljes keresletcsökkenésnek vagyunk tanúi, amelyet tovább árnyalt a kétciklusú képzés bevezetése, ami - legalább átmenetileg - csökkentette a levelező munkarendben tanulni vágyó, jellemzően idősebb korosztály továbbtanulási lehetőségeit (Veroszta 2012). Ez jól megmutatkozik abban, hogy 2001 és 2008 között mintegy felére csökkent a részidős képzésekben továbbtanulni kívánók száma, $\mathrm{s}$ azt követően - kisebb ingadozásokkal - megmaradt a nagyjából 30 ezer fős jelentkezői létszám (11. ábra).

A nappali képzésben a jelentkezői létszám csökkenése összességében kevésbé volt drasztikus, két nagyobb hullámtól eltekintve egy tartós, ám a létszámot tekintve nem túlságosan erőteljes csökkenés képe rajzolódik ki. Ehhez minden bizonnyal hozzájárul az is, hogy - amint a középfokú beiskolázási adatokból is kitünik - az elmúlt években egyre többen tanultak gimnáziumokban, amelyek a felsőfokú továbbtanulás jelentős bázisát adják. Bár nappali képzésre túlnyomórészt azok jelentkeznek, akik az adott évben vagy az azt pár évvel megelőző évben érettségiztek (az utóbbi évek adatai szerint az összes nappali képzésre jelentkező 90\%-a 25 év alatti, amennyiben pedig csak az alap-, osztatlan és felsőoktatási szakképzést nézzük, akkor $94 \%$ ez az arány), a felsőoktatás

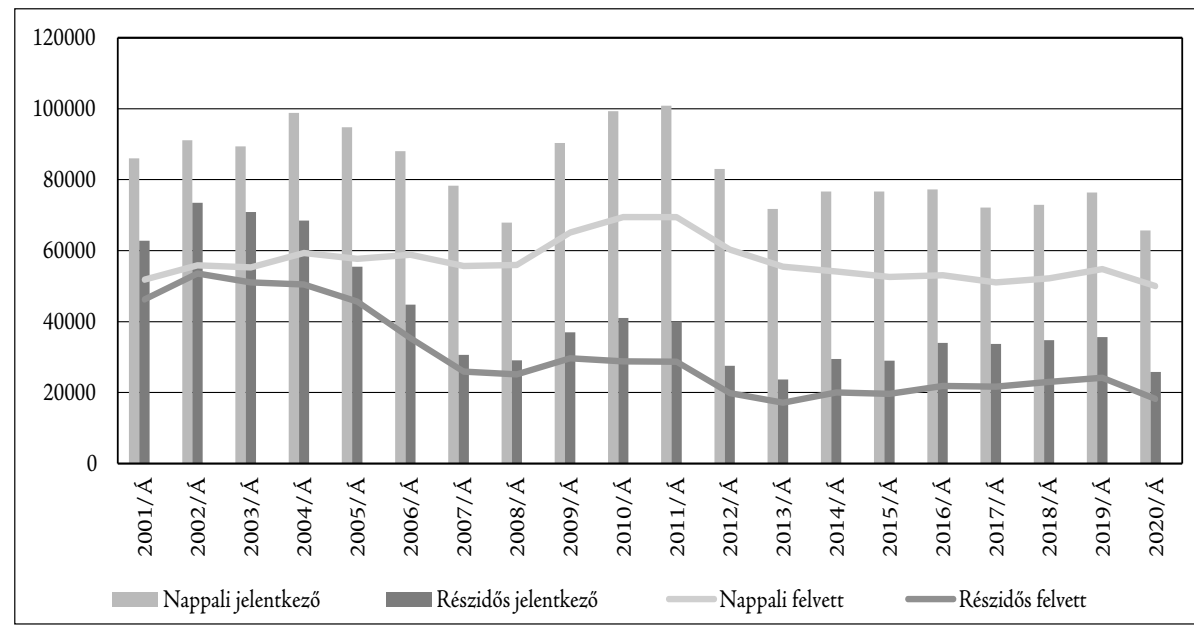

11. ábra: Az általános (Á) felvételi eljárásban jelentkezők és felvettek számának alakulása munkarend szerint (2001-2020). Forrás: felvi.hu 
demográfiai összefüggéseinek vizsgálatakor nem csupán munkarend szerint érdemes kettéválasztani az adatokat, hanem képzési formák szerint is. A bolognai rendszer életbelépésével ugyanis az egymásra épülő képzési szintek közül az alap-, az osztatlan és a felsőoktatási szakképzés épül közvetlenül az érettségire, a demográfiai hatások tehát leginkább itt ragadhatók meg.

A hosszabb idősor vizsgálatának kezdőéve 2006, amikor bevezetésre került a kétciklusú képzés, az alábbi ábrán pedig csak a nappali alap-, osztatlan és felsőfokú/felsőoktatási szakképzés első helyes jelentkezői létszámait összegeztük. Ezek a számok a trend jellegét tekintve követik a frissen érettségizettek létszámának változását, jóllehet meglehetősen nagy ingadozással (12. ábra). Az érettségizettek létszámában egyetlen év adata tér el jelentősen az általánosan csökkenő trendtől, ez a 2008-as év, ami a nyelvi előkészítő képzés 2004. évi indulásához köthető, aminek következtében a korábbiaknál kevesebben érettségiztek 2008-ban. Ez ugyan 2009-ben helyreállt, onnantól kezdve azonban az érettségizők létszámának csökkenése szinte folyamatos, tíz év alatt mintegy 20 ezer érettségiző fiatallal lett kevesebb.

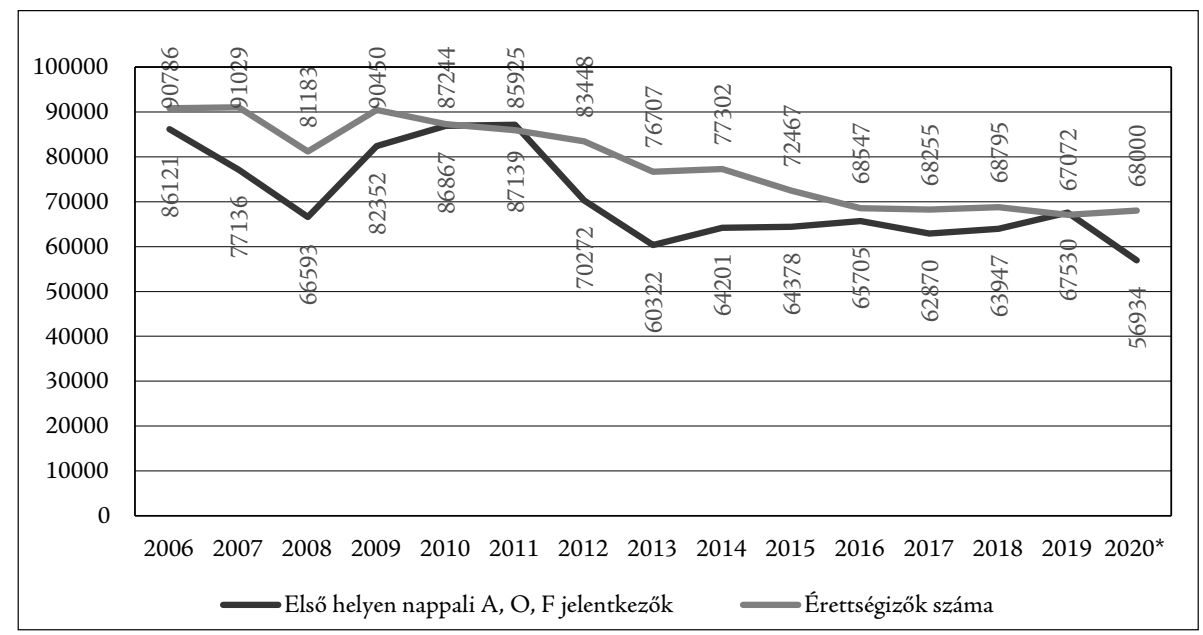

12. ábra: Az általános felvételi eljárásban első helyen nappali munkarendű alap-, osztatlan vagy felsőoktatási szakképzésre jelentkezők száma és az adott évben érettségizők létszáma (2006-2019). Forrás: felvi.hu és KSH

STADAT. https://www.ksh.hu/stadat/ (2.6.3. Végzettek a nappali és a felnőttoktatásban, 1990-)

*2020-ban az érettségizettek becsült létszáma az Oktatási Hivatal prezentációja alapján: https://www.oktatas. $\mathrm{hu} /$ kozneveles/erettsegi/prezentaciok_tanulmanyok

A jelentkezői létszámok ingadozásában egyrészt ennek a hatása mutatkozik meg, másrészt az is látszik, hogy a felvételi rendszert érintő minden változtatás is kihatással van a jelentkezők számára. 2012-ben, illetve 2013-ban is ez figyelhető meg, hiszen ebben az időszakban egyidejüleg számos változás történt (finanszírozási szabályok változása, tanárképzés és felsőoktatási szakképzés átalakítása, kötelező emelt szintű érettségi bevezetése több szakon, minimumponthatárok változása). Az általánosan elöírt kötelező emelt szintű érettségi előfeltétele az alap-és az osztatlan képzésben hasonlóan hatott a 2020. évi jelentkezési számokra is, mindamellett, hogy - miután ez a rendelkezés jó előre tudott volt - a korábbi évek számait kismértékben megemelte. 
A felsőoktatás nappali munkarendű alap-, osztatlan és felsőoktatási szakképzéseire nem csupán a frissen érettségizettek jelentkeznek, hanem az azt megelőző néhány év végzettjei is, de figyelembe véve, hogy a jelentkezők túlnyomó többsége a húszas évei elején van a jelentkezés évében, az érettségire épülő nappali munkarendü felsőfokú képzés elsődleges célcsoportja a legfeljebb három-négy éve érettségizetteké. Ezen belül évről évre kicsit változó, hogy milyen az arányuk a nappali képzésre jelentkezőkön belül az adott évben érettségizetteknek és a kicsit idősebbeknek, de az utóbbi néhány év átlagát vizsgálva egyértelműen látszik, hogy az alap- és az osztatlan, továbbá a felsőoktatási

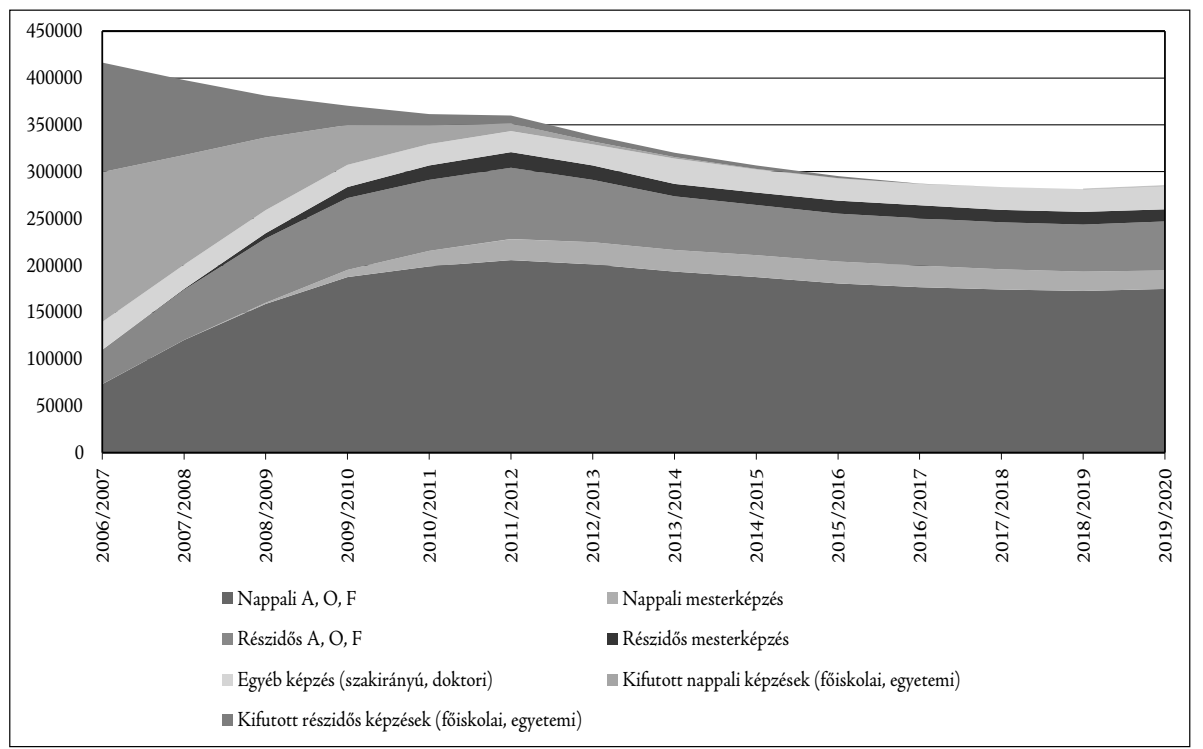

13. ábra: A hallgatók számának alakulása képzési szint és munkarend kombinációk szerint (2006-2019). Forrás: https://www.ksh.hu/stadat/ (2.6.11. Felsőoktatás, 1990-)

szakképzés nappali munkarendű képzéseire első helyen jelentkezők között csekély az öt évnél régebben érettségizettek aránya, s nyilvánvalóan ugyanez igaz a felvettekre is.

Miután a nappali képzésekre járók teszik ki a felsőoktatási hallgatók jelentős részét (az alap-, az osztatlan és a felsőoktatási szakképzésben egyértelműen ez a domináns képzési forma, s a mester-és a doktori képzésben is a többség nappali munkarendben tanul), viszont a demográfiai hatások éppen a nappali képzést érintik leginkább, a felsőoktatás hallgatói létszámának növelésében kitüntetett szerepük lehet a részidős képzéseknek, amelyek létszáma kevésbé függ a demográfiai folyamatoktól. Az idősebb generációk bevonzásával a szakirányú továbbképzés és a doktori képzés is eredményezhet némi létszámtöbbletet: míg az előbbi képzési formában az utóbbi néhány évben 16-20 ezer fö közöttiek a létszámok, a doktori képzés létszámai enyhe növekedést mutatnak. A doktori képzés esetén a növekvő létszám ugyanakkor félrevezető lehet, amennyiben figyelembe vesszük, hogy 2016-tól a korábbi háromévest felváltotta a négyéves képzés, ami önmagában is növeli a létszámot. Mindemellett azt sem szabad figyelmen kívül hagyni, hogy - a jelenlegi tendenciákat figyelembe véve - a doktori képzés fokozatosan 
egyre inkább a nappali képzések irányába tolódik: míg a 2006/2007-es tanévben a doktori képzésben részt vevők 65\%-a tanult nappali képzésben, 2018/2019-ben 85\%-os volt ez az arány.

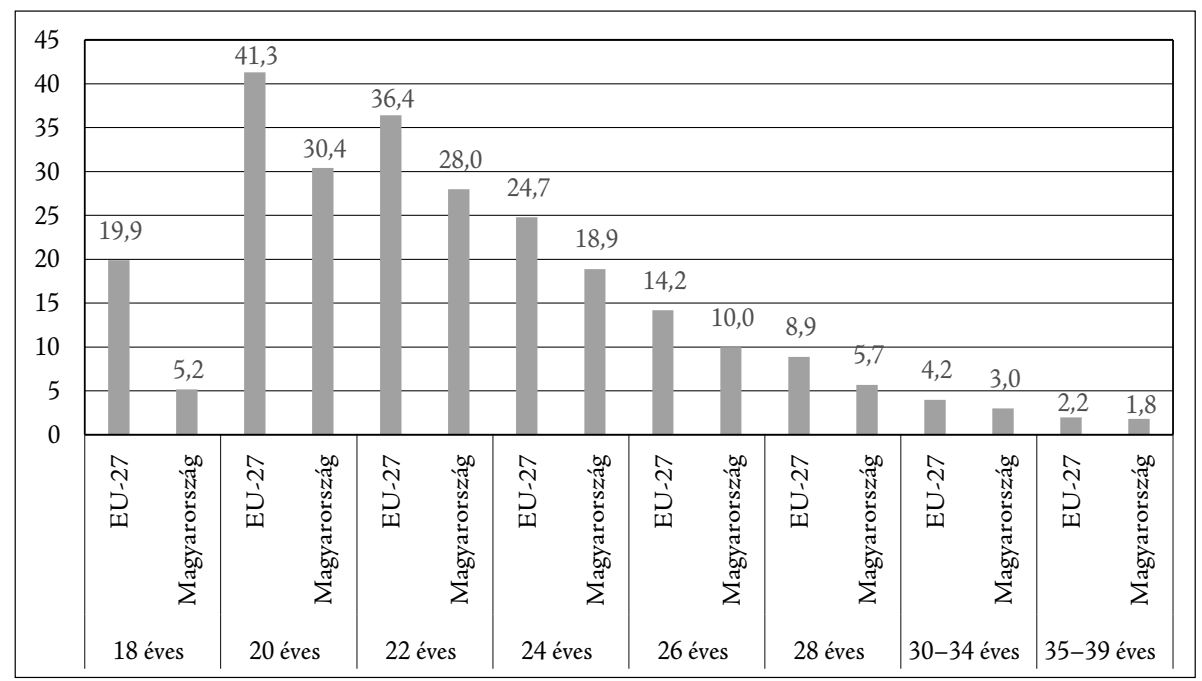

14. ábra: A felsőfokú képzésben részt vevők aránya a megfelelő korú népesség \%-ában (2018). Forrás: Eurostat (Students in tertiary education by age groups - as \% of corresponding age population)

Nemzetközi összevetésben egyébként a magyar felsőoktatásban tanulók korösszetétele nem tér el jelentősen az európai átlagtól. Elmaradás mutatkozik ugyanakkor a felsőoktatásban tanulók adott korosztályon belüli arányában, különösen a 20-24 éves korosztályban. Míg az EU-27 átlagában 2018-ban a 20 évesek 41,3\%-a vett részt valamilyen felsőfokú képzésben, addig Magyarországon 30,4\% (14. ábra). Az idősebb korosztályokban az eltérés jóval kisebb ugyan, de néhány északi országhoz képest jelentős az elmaradás: az 1000 lakosra jutó részvétel a 30 éves vagy efölötti korosztály körében nálunk átlagosan 20 fó, míg a hagyományosan magas részidős képzési szektorral rendelkező Finnországban vagy Svédországban 80 fö körüli.

Amennyiben tehát a felsőoktatási létszám növelése oktatáspolitikai cél, úgy - a demográfiai trendeket is figyelembe véve - két fókuszt érdemes szem elött tartani. Egyrészt a jelenleginél több fiatal bevonzása a felsőoktatásba, másrészt a felnőttképzés megerősítése oly módon, hogy az a munkaerőpiac számára releváns ismereteket nyújtson és a felsőoktatási intézmények is ki tudják használni meglévő kapacitásaikat. A demográfiai folyamatok lassabban befolyásolhatók, a frissen érettségizők száma egy ideig még biztosan csökkenni fog, s ez még akkor is problémát jelenthet, ha az adatok azt mutatják, hogy a gimnáziumokban érettségizettek száma jelenleg nem csökken olyan ütemben, mint a szakgimnáziumokban érettségizetteké. Ez a felsőoktatás szempontjából azért kulcsfontosságú, mert míg a gimnazisták közel háromnegyede felvételizik az érettségi évében, addig a szakgimnazistáknak csupán a negyede, s jóllehet ez utóbbi képzési típusból többen az azt követő 1-2 évben még beadják a jelentkezésüket, összességében a gimnáziumokban érettségizettek nagyobb eséllyel jelentkeznek és kerülnek be a felsőoktatásba. 


\section{Összegzés}

Írásunk a középiskolai és a felsőoktatási felvételi adatokat felhasználva mutatta be az elmúlt évtizedek beiskolázási trendjeit, fókuszálva az elmúlt másfél-két évtizedben végbemenő folyamatokra és korosztályi jellemzőkre.

A középiskolai beiskolázás adatai szerint egyrészt megállapítható, hogy a rendszerváltás utáni trend 2011 után megtört, a középiskolás korosztályon belül egyre csökken azok aránya, akik részt vesznek valamilyen középfokú képzésben, nemzetközi viszonylatban is a fejlett országok átlaga alá került Magyarország ebben a tekintetben. Másrészt a képzésben maradók preferenciái az általános képzés felé törekednek, a szakképzés struktúraváltása kifejezetten elriasztotta a tanulókat és szülőket a képzésbe való jelentkezéstől, ezen trenden kíván fordítani az oktatáspolitika az ismételt struktúraváltással, a technikumok bevezetésével. Bár a felvettek számát és arányát tekintve a szakképzésben többen tanulnak, mint az általános képzésben, amennyiben azonban csak az érettségit adó képzéseket vizsgáljuk, 2013-2018 között a gimnáziumi képzés térnyerése figyelhető meg. Az állami gimnáziumi képzésbe való bekerülést - különösen a 6 és 8 osztályos képzésben - egyre nagyobb szelekció kíséri.

A demográfiai folyamatok a felsőoktatásban is éreztetik hatásukat, hiszen a felsőoktatásba újonnan bekerülők jelentős hányadát adják a frissen érettségizettek. Az érettségi bizonyítványt szerzők száma az utóbbi 15 évben folyamatosan csökken, de ezt a felsőoktatási létszámok tekintetében némileg ellensúlyozni tudja, hogy a célzottan a felsőfokú továbbtanulásra felkészítő gimnáziumi képzéstípusban az érettségizettek száma kisebb ütemben csökkent, mint a szakképző intézményekben érettségizetteké. A felsőoktatásban ugyanakkor nemcsak a legfiatalabbak által preferált nappali képzéseknek, hanem a részidős képzéseknek is nagy szerepük van, s a nemzetközi adatok azt mutatják, hogy ezen a téren vannak még tartalékok. Mindazonáltal a felsőoktatási expanzió csúcspontján megfigyelhető létszámok már minden bizonnyal nem térnek vissza, hiszen azok eltérő társadalmi-gazdasági viszonyok mellett és a korábbról elhalasztott, ki nem elégített képzési igények következtében voltak csak reálisak.

\section{IRODALOM}

Fehérvári A. \& Híves T. (2017a) Trajectories in Hungarian Education - Transition to Secondary School. The New Educational Review, Vol. 48. No. 2. pp. 154-166.

Fenérvári A. \& Híves T. (2017b) Tanulói preferenciák, oktatáspolitikai szándékok. Educatio, Vol. 26. No. 4. pp. 567-580.

Garai O. \& KIss L. (2014) A felsőoktatási jelentkezések tendenciáinak alakulása 2010 és 2014 között. Felsőoktatási Mübely, No. 1. pp. 17-46.

Hermann Z. \& VArga J. (2016) Állami, önkormányzati, egyházi és alapítványi iskolák: részarányok, tanulói összetétel és tanulói teljesítmények. In: Kolosi T. - TóTH I. G. (eds) Társadalmi riport 2016. Budapest, Tárki. pp. 311-333.

Híves T. \& Kozma T. (2014) Az expanzió vége? Educatio, Vol. 23. No. 2. pp. 239-252.

Mártonfi Gy. (2019) Tanügyirányítás és struktúraváltás a hazai szakképzésben 2010 után. Educatio, Vol. 28. No. 2. pp. 240-254. https://doi.org/10.1556/2063.28.2019.2.3

OECD (2020) Education at glance 2020. Paris: OECD. 
Szemerszki M. (2014) A középiskolából a felsőoktatásba - jelentkezési és felvételi tendenciák. Felsőoktatási Mübely, No. 1.pp. 47-63.

Tomasz G. (2017) Erősödő egyházi jelenlét az oktatásban. Educatio, Vol. 26. No. 1. pp. 94-112.

Veroszta Zs. (2010) Az idősebb korosztály jelentkezési tendenciái. Felsőoktatási Mühely, No. 1. pp. 49-57.

Veroszta Zs. (2012) A felsőoktatás különböző szintjeire felvettek jellemzői. In: Szemerszki M. (ed.) Az érettségitöl a mesterképzésig. Továbbtanulás és szelekció. Oktatáskutató és Fejlesztő Intézet, Budapest.

A cikk a Creative Commons Attribution 4.0 International License (https://creativecommons.org/licenses/ by/4.0/) feltételei szerint publikált Open Access közlemény, melynek szellemében a cikk bármilyen médiumban szabadon felhasználható, megosztható és újraközölhető, feltéve, hogy az eredeti szerző és a közlés helye, illetve a CC License linkje és az esetlegesen végrehajtott módosítások feltüntetésre kerülnek. (SID_1) 